\title{
Spatial Conditions of a Children's Library Supporting Children's Development: With Prionity Given to User Benefit Criteria
}

\author{
어린이발달을 지원하는 어린이도서관 공간기준: 이용자편익기준을 중심으로 \\ Hyun-Jin Hong* \\ Mi Hee Kang**
}

\begin{abstract}
The purpose of this study was to select the evaluation criteria for the physical spaces of a children's library in an effort to back up children's development in a more positive and constructive manner, as the physical spaces of a children's library are likely to affect their development. Theories of children's developmental characteristics were reviewed, and user benefit criteria were analyzed, which were the basis of the spatial conditions to facilitate their development in consideration of the developmental characteristics of different stages and domains. And then conceptual words that corresponded to the concept of benefit and commonly appeared in earlier studies of children's libraries and children's spaces were selected to embody the concept of benefit. 12 conceptual words were presented as corresponding words of benefit, out of which the majority were selected from among the previously selected words and some were added by this researcher. Several libraries were reviewed by the 12 standards, and a spatial criteria checklist for a children's library that focused on benefits provided to growing children was provided.
\end{abstract}

\section{초 록}

이 연구는 어린이도서관의 물리적 공간이 어린이 발달에 영향을 미칠 수 있음을 인식하고 긍정적이고 발전적인 방향으로 어린이 발달을 지원할 수 있도록 평가기준을 수립하는 데 목적을 두고 있다. 이를 위해 먼저 이론적으로 어린이 발달 특성을 검토하고 단계별, 영역별 발달 특성을 적절하게 지원할 수 있는 공간요건의 토대인 이용자편익기준 을 분석하였다. 다음으로 이용자편익에서 편익이라는 개념을 구체화하기 위해 어린이도서관 및 어린이공간을 주제로 진행된 선행연구에서 공통적으로 사용되고 있는 편익에 대응되는 개념어들을 추출했다. 그리고 추출된 항목들을 비교분석하고 본 연구의 제시 항목을 추가하여 12 개의 개념어를 편익의 대체어로 제시하여 실제 도서관 공간에 적용시켰다. 마지막으로 어린이에게 제공되는 편익 차원에 초점을 맞춘 어린이도서관 공간기준 체크리스트를 제시하 였다.

Keywords: children's developmental characteristics, spatial criteria for children, spatial conditions for a children's library, user benefit criteria

어린이 발달특성, 어린이 공간기준, 어린이도서관 공간기준, 이용자편익기준

* Professor, Department of Library and Information Science, Chonnam National University (hjhong@chonnam.ac.kr)

** Lecturer, Department of Library and Information Science, Chonnam National University (mhkang@hanmail.net)

- Received : 27 May 2010 - Revised : 4 June 2010 - Accepted : 14 June 2010

- Journal of the Korean Society for Information Management, 27(2): 173-199, 2010. [DOI:10.3743/KOSIM.2010.27.2.173] 


\section{Introduction}

There is lately a growing concern for children's libraries, and a lot of studies of the libraries are under way. The number of newly constructed children's libraries is on the rise, and existing children's libraries and the children's rooms of public libraries are increasingly in wide use as well. At this point of time, one of major issues regarding children's libraries is about children's developmental characteristics. Children are in the developmental stage to undergo physical and mental changes and grow amid continuing interaction with surrounding environments, which is one of their primary characteristics (Sherman 2005). So the kinds of environments that could affect their development in a positive and constructive way should be created. A children's library is one of the surrounding environments to play a crucial role in their growth, and it's needless to say that the library should be designed to back up their growth and development. However, it's never an easy task to prepare the sorts of spatial environments that could back up their development. It requires a multidisciplinary approach, and not many studies have ever paid attention to spatial concepts, spatial function and spatial guidelines from the perspective of developmental theories. This study intended to seek spatial conditions geared toward offering positive and constructive support to children's development on the assumption that the physical environments of a children's library might affect their development. The purpose of this study was, therefore, to examine children's developmental characteristics and to develop a checklist of required spatial conditions of a children's library on the premise that a children's library should support children's development. The checklist would be made as follows: The indicators of the spatial criteria backing up children's development would be defined as benefits in conjunction with user benefit criteria, and conceptual words of space that could embody the term benefit would be selected from earlier studies of children's libraries and spaces. Whether the prepared conceptual framework could support children's development would be checked by applying the framework in reality, and then a finalized spatial criteria checklist for a children's library would be provided, which would focus on offering benefits to children, namely backing up growing children.

\section{Children's Development and Spatial Criteria}

\subsection{The Characteristics of Children's Development}

Researchers have made different definitions of development. In general, that is defined as what's comprehensive of physical and psychological changes that take place during the dynamic process of ups and downs in genetic factors and social experiences. Researchers take different views of developmental stages as well. Throndike (1949) classified the developmental stage into six: infanthood, early childhood, childhood, transitional period, early adulthood and late adulthood. Hurlock (1964) divided it into eight: 
fetal period, early childhood, the first half of childhood, the second half of childhood, adolescence, adulthood, middle age and old age. Cho Bok-hee (2009) classified it into five: insemination-birth, infanthood ( 0 to 24 months), early childhood (ages 2 to 6 ), childhood (ages 6 to 12), and adolescence (ages 12 to 20 ).

There are elastic potentials of growth and development for children who are still immature. If they fail to make the right growth at the right time, however, it poses a severe threat to their development and is likely to take a huge toll on their later development. The great possibilities and rapid speed of development imply that children are in a critical period of life. They are in the best period of development, and one kind of development leads to another sort of development. One significant fact that shouldn't be overlooked is that the degree of development varies with age and developmental stage and from child to child. Therefore the degree of physical, cognitive, emotional and social development in infanthood, early childhood and childhood should be checked, which is roughly shown in Table 1 (Cho 2009; Kang 2005). In this study, children's developmental stage was classified into three: infanthood (ages 0 to 2), early childhood (ages 3 to 6) and childhood (ages 7 to 12). And four domains were selected as developmental domains: physical, cognitive, emotional and social domains. There are elastic potentials of growth and development for children who are still immature, but they will face tremendous difficulties in late development if they are unable to make the right growth at the right time. Specifically, childhood is a critical period for physical, intellectual and personality development, on which their lives hinge. Hence the right understanding of the developmental characteristics of childhood is vital.

The followings are brief explanations about the views of researchers, which should be taken into account regarding the spatial construction of a children's library in association with physical, cognitive, emotional and social development.

(1) Physical Development and Children's Spaces

In terms of physical development, the needs for the design of children's spaces could be described as below:

First, children aged between 2 and 5 are in different stages of motor development. Even children who were born at the same time are likely to be different from one another in height, weight and motor development (Gibson 1972). Given the fact, they should be provided with appropriate environments tailored to their developmental level and ability to achieve the best development. That is, a variety of feasible solutions for the design of children's spaces should be offered in light of their developmental stages. The furniture and facilities used by children should all be different in size, and diverse levels of furniture and facilities that are respectively simple and complicated to use should be prepared. If the spaces are separated by age, their design may be at a different level as well, and even a single space can be designed to be variable so that children with different motor skills could fit into the space. 
176 Journal of the Korean Society for Information Management, 27(2), 2010

〈Table 1〉 Children's developmental characteristics by stage and domain

\begin{tabular}{|c|c|c|c|}
\hline & Infanthood (ages 0 to 2) & Childhood (ages 3 to 6 ) & Childhood (ages 7 to 12 ) \\
\hline $\begin{array}{l}\text { The } \\
\text { characteristics } \\
\text { of physical } \\
\text { development }\end{array}$ & $\begin{array}{l}\text { - Attainment of the fastest physical } \\
\text { growth (called the first rapid growth } \\
\text { stage } \\
\text { - The height and weight are twofold } \\
\text { and threefold respectively at the age } \\
\text { of } 2 \text {. } \\
\text { - Rapid development of bones and } \\
\text { muscles. } \\
\text { - Rapid development of brains and the } \\
\text { nervous system. } \\
\text { - Development of major and minor } \\
\text { muscles. }\end{array}$ & $\begin{array}{l}\text { - Continuing growth. } \\
\text { - Maturity of brains and the nervous } \\
\text { system. } \\
\text { - Development of new motor skills. } \\
\text { - Development of new cognitive ability. } \\
\text { - Rapid development of major and minor } \\
\text { muscles. } \\
\text { - Rapid development of motor function. }\end{array}$ & $\begin{array}{l}\text { - Steady, slow physical development. } \\
\text { - Rapid growth at the end of childhood. } \\
\text { - Reinforced, elaborated motor function. } \\
\text { - Nearly perfect motor function of major } \\
\text { muscles. } \\
\text { - Nearly perfect motor function of minor } \\
\text { muscles. } \\
\text { - Great individual variances in motor } \\
\text { function. }\end{array}$ \\
\hline $\begin{array}{l}\text { The } \\
\text { characteristics } \\
\text { of cognitive } \\
\text { development }\end{array}$ & $\begin{array}{l}\text { - The sensory- motor stage of Piaget's } \\
\text { theory. } \\
\text { - Acquisition of knowledge by sensory } \\
\text { experiences. } \\
\text { - The development of thinking is under } \\
\text { way. } \\
\text { - The conceptual development of object } \\
\text { permanence. }\end{array}$ & $\begin{array}{l}\text { - The preoperational stage of Piajet's } \\
\text { theory. } \\
\text { - Stiff way of thinking. } \\
\text { - Judge things by appearance only. } \\
\text { - Being symbolic and egocentric. } \\
\text { - Hylozoic, intuitive thinking. } \\
\text { - Increase in memory capacity. }\end{array}$ & $\begin{array}{l}\text { - The concrete operational stage of } \\
\text { Piajet's theory. } \\
\text { - Logical, abstract thinking faculty. } \\
\text { - Formation of the concepts of } \\
\text { decentralization and categorization. } \\
\text { - Formation of the concepts of ranking } \\
\text { and preservation. } \\
\text { - Improvement of attention, memory } \\
\text { and language ability. } \\
\text { - Development of reading and writing } \\
\text { skills. }\end{array}$ \\
\hline $\begin{array}{l}\text { The } \\
\text { characteristics } \\
\text { of emotional } \\
\text { development }\end{array}$ & $\begin{array}{l}\text { - The first exhibited emotion is } \\
\text { unpleasant one. } \\
\text { - Being in a state of undifferentiated } \\
\text { excitedness. } \\
\text { - The same emotion lasts just a very } \\
\text { short time. } \\
\text { - Very intense display of emotion. } \\
\text { - Frequent display of emotion. } \\
\text { - Large disparities by age and great } \\
\text { individual variances. }\end{array}$ & $\begin{array}{l}\text { - Little differences from infanthood } \\
\text { emotion. } \\
\text { - Continuance of various kinds of emotions } \\
\text { created before being two years old. } \\
\text { - Expanded sphere of activity, emotional } \\
\text { tension. } \\
\text { - Display of fear, anger and curiosity. } \\
\text { - Need for balance between two different } \\
\text { kinds of conflicting emotions such as } \\
\text { autonomy vs. shame or initiative vs. } \\
\text { guilt. }\end{array}$ & $\begin{array}{l}\text { - Formation of self-concept and } \\
\text { self-esteem. } \\
\text { - Formation of egocentric self-esteem. } \\
\text { - Being able to control oneself and be } \\
\text { aware of society. } \\
\text { - Development of understanding about } \\
\text { others. } \\
\text { - Natural display of pride and guilt and } \\
\text { better understanding of the rules of } \\
\text { emotional display. }\end{array}$ \\
\hline $\begin{array}{l}\text { The } \\
\text { characteristics } \\
\text { of social } \\
\text { development }\end{array}$ & $\begin{array}{l}\text { - Expression of intention by smiling and } \\
\text { crying. } \\
\text { - Dependence on the mother. } \\
\text { - Imitation of others action at the age } \\
\text { of } 1 \text {. } \\
\text { - Relatively clear representation of } \\
\text { sociability toward others through } \\
\text { expression of needs }\end{array}$ & $\begin{array}{l}\text { - Building social relationships through } \\
\text { play. } \\
\text { - Acquisition of social roles through play. } \\
\text { - Development of sex-role concepts and } \\
\text { sex roles. } \\
\text { - The first socialization through family. } \\
\text { - Increase in social interaction due to } \\
\text { verbal development triggered by } \\
\text { symbolic thinking. }\end{array}$ & $\begin{array}{l}\text { - Entrance into elementary school and } \\
\text { formation of peer groups. } \\
\text { - Abiding by the rules of peer group. } \\
\text { - Formation of the concepts of } \\
\text { cooperativeness and compromise. } \\
\text { - Acquisition of norms necessary for } \\
\text { socialization. } \\
\text { - Development of socializing and } \\
\text { morality. } \\
\text { - School plays a vital role in socialization. }\end{array}$ \\
\hline
\end{tabular}

Second, children are still devoid of coordination, judgment and ability to react immediately, and they don't yet gain a lot of experiences (Osmon 1973). Considering the fact, every space newly provided to them should be designed to let them recognize that it is new and strange, and that also should be designed to ensure security in order for them to do something without being interrupted by adults.
Dangerous zones should be screened off, and visual clues should be provided for them to recognize there's something dangerous. Safety materials such as nonslip materials or safety glass should be utilized, and every corner of facilities should be round.

Third, children like to test their own physical ability and make a challenge to find out what they can and cannot do. If the given environments don't allow 
them to do that, they do that in another place (Gallahue 1979), and the kinds of facilities and environments that let them test what they can do should subsequently be created. For instance, there should be a place where they can play going up and down or read books lying down.

(2) Cognitive Development and Children's Spaces

Children are typically expected to behave in a particular manner in a particular developmental stage. They have a natural desire to learn about things around themselves, and physical environments provided to them should be designed to pique their curiosity. The followings are explanations about several related theories:

First, children have a different need for information on organisms depending on their past experiences. Those who have been exposed to lots of information are likely to ask for a lot of information in the future, and those who have been stimulated by lots of information are likely to try to know more about the world around them (Glanzer 1958). Given those arguments, spaces should be designed to give a lot of easily recognizable stimuli that are all differentiated in terms of complexity, theme and degree of difficulty. Accordingly, a children's library should be planned to serve as major sources of necessary information and experiences. That is, that should function as a sort of a small world that offers sensual experiences as many as possible.

Second, children who are exposed to new things or new attributes of the ecosystem such as blocks, puzzle games and color get to respond to those things in a better and more sensitive manner. New facts and new things provide them with diverse pieces of information (Herron and Sutton-Smith 1971). So a children's library should be equipped with an exhibition hall where catchy things or what to learn can be placed on display in diverse ways to give stimuli to children.

Third, curiosity is a catalyst of learning, and children's curiosity should be satisfied in a manner to be appropriate at their developmental stage (MaCandless 1967). Curiosity is engendered when they encounter something marvelous, surprising, complex or contradictory, and when they are confronted with uncertainty or conceptual conflicts (Berlynne and Frommer 1966). Considering those arguments, things and activity spaces to which they are exposed should be marvelous, surprising, complicated, contradictory or uncertain.

(3) Emotional Development and Children's Spaces

There are several theories on children's spaces and emotional development:

First, children are able to trust someone or something when they find themselves to be placed in safe environments (McCandless and Evans 1973). Given this argument, separate zones of play where they could play without any restraints and being interrupted by others should be offered, and various sorts of spaces where they can be engaged in group activities or do something alone should be prepared. There should be a clear distinction between the zones of play for different purposes in order for them to interact with one another without being worried about the infringement of privacy. 
Second, they are able to be autonomous and strong-willed the best when they can strike a balance among their reason, right of choice, spontaneity, challenging spirits and proper control (Hendrick 1975). Considering this theory, children should be let off and allowed to do a lot of activities. Namely, they should be allowed to do what they like to do without any restraints.

Third, children feel fear when they face new situations or something they don't like or when they depart from familiar environments (Gallahue 1976). Given this view, their sphere of activity should be expanded, and the sorts of environments that are understandable should be prepared. When they are exposed to something new, what they like or get used to should be utilized carefully not to make them dislike it, and they should be allowed to do complicated play as much as possible. A variety of multilevel activities should be well linked so that they could move onto a new activity in a natural way.

(4) Development of Sociability and Children's Spaces

Children should acquire particular skills needed to survive as eligible members of society. They learn social skills to be received as members of a specific group to which they belong, and learn to use their ability, make a compromise and share things with others. All these things should be acquired in infanthood. There are several theories about sociability development:

First, they gradually get to play even virtual roles when they are two to five years old (Hendrick 1975).
They can understand how others feel while they are engaged in association play, role play, etc., and they become compassionate and considerate (Kohlberg 1969). Given this view, a stage and necessary facilities should be prepared for them to do role play.

Second, children can build social relationships with their peers more easily when they are less dependent on them (Butler, Gotts and Guinsenburg 1975). Considering this argument, adults who are children's guardians should serve as observers, not active participants, and the sorts of environments that stimulate them to find out their own needs to do what they like to do should be offered.

\subsection{User Benefit Criteria}

\subsubsection{The Concept of User Benefit Criteria}

Many researchers who have explored the relationship between man and environments have tried to grasp how environments can give the best satisfaction to users. Murtha (1976)'s user benefit criteria were produced in an effort to do that. Murtha thought that successful physical environments should give appropriate affordance to users from various angles, and approached the affordance system of environments based on what positive benefits users can get from the environments. Murtha's user benefit criteria were selected by analyzing a wide variety of studies. The user benefit criteria are a theoretical framework that systemized the concept of affordance provided by environments to users on the basis of the concept of benefit, and the criteria are guidelines or standards of environmental evaluation that indicate the relation- 
ship between physical environments and human behavior from a comprehensive perspective. Being officially introduced in 1984 in Psychology Environment, the criteria have been in wide use in diverse fields. One notable fact is that affordance is applied flexibly, not in a uniform manner, depending on user characteristics. For instance, the application of affordance in a library may be different depending on whether it is for adults or children. The way of applying affordance may not be the same even in institutions for children, and it may be different according to the grade of educational institutions. That's why it matters for many researchers. Another noteworthy fact is that applicable, structured and systemized information is available in relation to affordance. For instance, the benefits that users can get from environments have been categorized into four major categories and 21 minor ones, which structurized affordance that physical environments must have from the perspective of benefit users can get from physical environments on the assumption that the highly prized environments should give appropriate support to the users in various ways. The four major categories involve behavioral facilitation, physiological maintenance, perceptual maintenance and social facilitation. The followings give detailed explanation on the four major and 21 minor categories:

(1) Behavioral facilitation refers to affordance of environments that stimulates users to perform various actions or do it easily. That means to support them to do something in an efficient manner.
(2) Physiological maintenance refers to affordance of environments that allows users to feel pleasant physiologically or biologically and to stay healthy while performing an action. That is comprehensive of every aspect of environments affecting the physiological process and interacting with users, which involves environmental elements that are sensual or make contact with the body of users.

(3) Perceptual maintenance refers to affordance of environments that is related to whether the meaning of environments is properly understood by users. That has a firsthand impact on psychological comfortableness and exerts a secondhand influence on their basic behavior or physical health.

(4) Social facilitation refers to affordance of environments that controls and facilitates social interaction. This is accentuated in association with the trend in modern architecture that a lot of people are housed in limited spaces, and interaction and cooperativeness among different groups are stressed in conjunction with that.

Thus, the user benefit criteria denote the types and standards of benefits that environments (spaces) should provide to users. Table 2 shows the summary of the above explanations.

\subsubsection{Application of the User Benefit Criteria to a Children's Library}

In order to determine the spatial construction con- 
180 Journal of the Korean Society for Information Management, 27(2), 2010

〈Table 2〉 Category and contents of Murtha's User Benefit Criteria

\begin{tabular}{|c|c|c|c|}
\hline \multicolumn{2}{|r|}{ Upper sphere } & \multicolumn{2}{|r|}{ Lower sphere } \\
\hline 4 spheres & Contents & 21 spheres & Contents \\
\hline \multirow{6}{*}{$\begin{array}{l}\text { Behavioral } \\
\text { facilitation }\end{array}$} & \multirow{6}{*}{$\begin{array}{l}\text { Appearance of inducement } \\
\text { or facilitation so that user's } \\
\text { several behaviors can be } \\
\text { possible }\end{array}$} & Overall conformance & $\begin{array}{l}\text { Appearance of having basic conditions necessary for user's } \\
\text { specific behavior }\end{array}$ \\
\hline & & Functional conformance & $\begin{array}{l}\text { Appearance of functional support for user's behavior in physically } \\
\text { environmental elements }\end{array}$ \\
\hline & & Operational conformance & Appearance of possibility for user's environmental operation \\
\hline & & Stimulus conformance & $\begin{array}{l}\text { Appearance of conformance in information necessary for using } \\
\text { environment }\end{array}$ \\
\hline & & Spatial conformance & $\begin{array}{l}\text { Whether the spatial composition and distribution conform with } \\
\text { the expectation value }\end{array}$ \\
\hline & & Contingent conformance & $\begin{array}{l}\text { Appearance of existence in possibility of accepting user's future } \\
\text { behavior }\end{array}$ \\
\hline \multirow{6}{*}{$\begin{array}{l}\text { Physiological } \\
\text { maintenance }\end{array}$} & \multirow{6}{*}{$\begin{array}{l}\text { Whether or not supporting } \\
\text { user's physiological and } \\
\text { biological health }\end{array}$} & Support conformance & $\begin{array}{l}\text { Whether or not supporting user's body in physical element of } \\
\text { space }\end{array}$ \\
\hline & & Climate conformance & $\begin{array}{l}\text { Whether the environmental climate supports user in order to } \\
\text { be comfortable physiologically }\end{array}$ \\
\hline & & Stimulus regulation & $\begin{array}{l}\text { Appearance of the stimulus regulation in the obstacle or } \\
\text { inconvenient factor of user's behavior }\end{array}$ \\
\hline & & External regulation & $\begin{array}{l}\text { Whether or not regulating the external elements, which become } \\
\text { physiological inconvenience and risk factor to user }\end{array}$ \\
\hline & & Hazard regulation & $\begin{array}{l}\text { Appearance of removing environmental element, which becomes } \\
\text { a cause for injury or hazard }\end{array}$ \\
\hline & & Physical endurance & $\begin{array}{l}\text { Appearance of preventing hazard element available for } \\
\text { occurrence by a change or modification }\end{array}$ \\
\hline \multirow{4}{*}{$\begin{array}{l}\text { Perceptual } \\
\text { maintenance }\end{array}$} & \multirow{4}{*}{$\begin{array}{l}\text { Appearance of supporting } \\
\text { health of having influence } \\
\text { upon a sense of physical } \\
\text { comfort }\end{array}$} & Perceptual consonance & $\begin{array}{l}\text { Whether the external design satisfies expectation value for } \\
\text { environment }\end{array}$ \\
\hline & & Operational invitation & $\begin{array}{l}\text { Whether the environmental design can propose user's behavioral } \\
\text { direction }\end{array}$ \\
\hline & & Sensory invitation & $\begin{array}{l}\text { Whether the environment is perceived sensationally as the } \\
\text { background of main activity }\end{array}$ \\
\hline & & Sensory conformance & $\begin{array}{l}\text { Appearance of conformance in stimulus elements available for } \\
\text { sustaining user's interest }\end{array}$ \\
\hline \multirow{5}{*}{$\begin{array}{l}\text { Social } \\
\text { facilitation }\end{array}$} & \multirow{5}{*}{$\begin{array}{l}\text { Appearance of promoting to } \\
\text { the desirable level by } \\
\text { regulating social interaction }\end{array}$} & Social invitation & Whether environment leads desirable social behavior \\
\hline & & Social observability & $\begin{array}{l}\text { Appearance of supporting external information for user's social } \\
\text { interaction }\end{array}$ \\
\hline & & Social convergence & $\begin{array}{l}\text { Appearance of the design to the space available for natural } \\
\text { gathering for social interaction }\end{array}$ \\
\hline & & Social isolation & $\begin{array}{l}\text { Appearance of existence in space available for shunning from } \\
\text { the undesired social contact }\end{array}$ \\
\hline & & Social accommodation & $\begin{array}{l}\text { Whether social characteristic supports social interaction and } \\
\text { communication }\end{array}$ \\
\hline
\end{tabular}

ditions of a children's library in compliance with Murtha's user benefit criteria, whether the physical environments of the library give appropriate support to children who use it should be checked. It means to examine the affordance system of the children's library. The affordance system refers here to benefits provided to children, and it's now needed to select conceptual words to evaluate the benefits. So conceptual words related to benefit were extracted from earlier studies on children's libraries and children's spaces to give an explanation on what benefits are, and a spatial criteria checklist of a children's library 
is presented based on the user benefit criteria.

a comparative analysis of the benefit items of a child-

Table 3 shows the benefit items selected from earren's library presented by different researchers. lier studies on children's libraries, and Table 4 shows

〈Table 3〉 The preceding researches and the benefit items on children's library

\begin{tabular}{|c|c|c|c|}
\hline Types & Research titles & Research contents & Benefit items \\
\hline \multirow{6}{*}{$\begin{array}{l}\text { Children's } \\
\text { library }\end{array}$} & $\begin{array}{l}\text { A study on children's reading space and } \\
\text { behavior at children's library, } \\
\text { Gang Geon-hae, } 2006\end{array}$ & $\begin{array}{l}\text { Systematization into the behavior of using } \\
\text { space by observing children's reading } \\
\text { behavior }\end{array}$ & $\begin{array}{l}\text { Security, flexibility, ease, scale, } \\
\text { accessibility, softness, privacy }\end{array}$ \\
\hline & $\begin{array}{l}\text { A study on spatial composition of children's } \\
\text { library through comparing types, } \\
\text { Park Soo-mi, } 2005\end{array}$ & $\begin{array}{l}\text { Suggestion of space and scale necessary for } \\
\text { children's library }\end{array}$ & $\begin{array}{l}\text { Security, flexibility, ease, scale, } \\
\text { comfort, territoriality, } \\
\text { maintenance }\end{array}$ \\
\hline & $\begin{array}{l}\text { A study on a plan for constructing children's } \\
\text { library, Shin Hyen-jeong, } 2005\end{array}$ & $\begin{array}{l}\text { Analysis on architectural characteristic, type, } \\
\text { and spatial composition system in children's } \\
\text { library }\end{array}$ & Security, flexibility, ease, scale \\
\hline & $\begin{array}{l}\text { A plan for renovation of children's public } \\
\text { library according to children's play behavior, } \\
\text { Oh Ji-seon, } 2005\end{array}$ & $\begin{array}{l}\text { A plan for space according to children's } \\
\text { behavioral characteristic and play behavior }\end{array}$ & $\begin{array}{l}\text { Security, flexibility, ease, } \\
\text { comfort, convenience }\end{array}$ \\
\hline & $\begin{array}{l}\text { A study on the interior space of children's } \\
\text { library for preschoolers, Choi Jin-hee, } 2005\end{array}$ & $\begin{array}{l}\text { A theory on toddlers physical and mental } \\
\text { characteristics, and an analysis by real case }\end{array}$ & $\begin{array}{l}\text { Security, flexibility, ease, scale, } \\
\text { comfort, territoriality, health, } \\
\text { convenience }\end{array}$ \\
\hline & $\begin{array}{l}\text { A study on a plan for indoor space of children's } \\
\text { library: Centering on the spatial composition } \\
\text { and furniture distribution of children's library } \\
\text { targeting preschoolers, Park Ji-min, } 2002\end{array}$ & $\begin{array}{l}\text { Suggestion of problems and improvements } \\
\text { in operating children's room }\end{array}$ & $\begin{array}{l}\text { Security, flexibility, ease, scale, } \\
\text { comfort, softness }\end{array}$ \\
\hline \multirow{3}{*}{$\begin{array}{l}\text { Children's } \\
\text { public library }\end{array}$} & $\begin{array}{l}\text { A study on design of children's reading room } \\
\text { within public library approached by a concept } \\
\text { of children's development psychology, } \\
\text { Kim Hee-jeong, } 2005\end{array}$ & $\begin{array}{l}\text { Analysis of children's behavior based on a } \\
\text { psychological theory in children's } \\
\text { development, suggestion of a plan for } \\
\text { user-oriented space }\end{array}$ & $\begin{array}{l}\text { Security, flexibility, ease, scale, } \\
\text { comfort, territoriality, health, } \\
\text { motility }\end{array}$ \\
\hline & $\begin{array}{l}\text { A study on furniture distribution according } \\
\text { to a plan for space of reading room for } \\
\text { children's public library, Gang Yoon-ho, } 2004\end{array}$ & $\begin{array}{l}\text { A plan for the spatial composition and the } \\
\text { furniture distribution according to problems } \\
\text { and improvements in children's reading room }\end{array}$ & $\begin{array}{l}\text { Security, flexibility, ease, scale, } \\
\text { health, convenience, privacy, } \\
\text { maintenance }\end{array}$ \\
\hline & $\begin{array}{l}\text { Analysis on the actual condition for our } \\
\text { country's children's library, Lee Soo-yeon, } \\
2002\end{array}$ & $\begin{array}{l}\text { Suggestion of policy by surveying budget, } \\
\text { facilities, and user satisfaction of children's } \\
\text { reading room for public libraries where are } \\
\text { located in Seoul }\end{array}$ & $\begin{array}{l}\text { Security, child scale, } \\
\text { accessibility, comfort }\end{array}$ \\
\hline
\end{tabular}

$\langle$ Table 4〉 Benefit items on children's library by researcher

\begin{tabular}{c|c|c|c|c|c|c|c|c}
\hline \multicolumn{4}{c|}{ Children's library } & \multicolumn{3}{c}{ Children's room for public library } \\
\hline $\begin{array}{c}\text { Gang Geon-hae } \\
(2006)\end{array}$ & $\begin{array}{c}\text { Park Soo-mi } \\
(2005)\end{array}$ & $\begin{array}{c}\text { Shin Hyen-jeong } \\
(2005)\end{array}$ & $\begin{array}{c}\text { Oh Ji-seon } \\
(2005)\end{array}$ & $\begin{array}{c}\text { Choi Jin-hee } \\
(2005)\end{array}$ & $\begin{array}{c}\text { Park Ji-min } \\
(2002)\end{array}$ & $\begin{array}{c}\text { Kim Hee-jeong } \\
(2005)\end{array}$ & $\begin{array}{c}\text { Gang Yoon-ho } \\
(2004)\end{array}$ & $\begin{array}{c}\text { Lee Soo-yeon } \\
(2002)\end{array}$ \\
\hline Security & Security & Security & Security & Security & Security & Security & Security & Security \\
\hline Flexibility & Flexibility & Flexibility & Flexibility & Flexibility & Flexibility & Flexibility & Flexibility & Accessibility \\
\hline Ease & Ease & Ease & Ease & Ease & Ease & Ease & Ease & Comfort \\
\hline Scale & Scale & Scale & Convenience & Scale & Scale & Scale & Scale & Scale \\
\hline Accessibility & Comfort & - & Comfort & Comfort & Comfort & Comfort & Health & - \\
\hline Softness & territoriality & - & - & territoriality & Softness & territoriality & Convenience & - \\
\hline Privacy & Maintenance & - & - & Health & - & Health & Privacy & - \\
\hline- & - & - & - & Convenience & - & Motility & Maintenance & - \\
\hline
\end{tabular}


(1) Benefit Items Based on Earlier Studies of Children's Spaces

A child-oriented design is considered most important in spatial planning for children, which denotes that children's developmental level, interest and needs should be taken into consideration when children's spaces are designed (Lim Jae-taek 1995). The term child-oriented refers to affordance for children, and could be substituted by another term benefit that is used in the user benefit criteria (Lee Yeon-sook 1997). Earlier studies give the following explanations on the concept of benefit:

Many researchers have taken consideration on a wide variety of elements. Kostelnik (1997) argued that the ultimate goal of a children's space is to provide environments in response to the needs of children who are all different in age, cultural background and developmental stage, and he put emphasis on seven elements involving security, health, comfortableness, the size of the body, flexibility, movement and option. Sanoff (1995) turned his attention to the interrelationship between a child development program and physical space and stressed four components based on the functional requirements of activity zones: flexibility, surface, privacy and visual connection. Moore (1987) believed that six components should be considered when a children's space is assessed and when guidelines about the planning and design of a children's space are formulated: accessibility, security, challenge, clarity, flexibility and variety. Greenman (1998) dealt with the concept of spatial design appropriate for the developmental characteristics of preschoolers in detail, especially the features that are significant in terms of child development. He placed importance on 11 components as the affordance requirements of a children's space: movement, comfortability, self-esteem, control, softness, challenge, privacy, order, security, health and flexibility. Castaldi (1979) considered the functionality and economy of a building to be additionally important in association with the planning of a children's space, and emphasized 10 components including sufficiency, appropriateness, efficiency, economy, security, health, convenience, variability, adaptability and flexibility. Decker and Decker (1976) argued that children's developmental level, interest and needs should take precedence over the nature or philosophical backdrop of a children's space, and then pointed out six components as the design requirements of the space: security, appropriateness, barrier-free design, efficiency, flexibility and economy.

Thus, a wide variety of components have been regarded as the elements of design. The followings are explanations on Greenman (1988)'s eleven components based on the definitions of Greenman (1988), Olds (1989) and Weinstein (1987):

(1) Security: A lot of researchers view security as one of major concepts of children's environments and mostly focus on the security of physical facilities. What matters here is that although security is the most fundamental concept, excessive concerns for that and excessive restrictions are likely to curb children's development or produce undesirable results. Children behave in an aggressive manner when there isn't a sufficient activity space they prefer. It implies that a safe activity space needs a safe arrangement 
of furniture and equipment, and that the space should be arranged not to make too many children get together in a particular part of it. As the level of danger differs with developmental stages, the furniture should be arranged properly in light of the developmental stage of users.

(2) Comfortability: Children react when they feel they are in a safe and pleasant space. The preparation of pleasant and comfortable environments serves to step up the development of their attention and memory and to let them take a rest and refresh themselves. To meet the condition of comfortability, it's required to give heed to sameness within difference, finish materials, spatial variety and light.

(3) Flexibility: Decker and Decker (1976) viewed flexibility, which refers to satisfying all the needs of individuals and groups, as one of the primary factors of children's facilities from the standpoint of social interaction. It means that a children's space should meet children's needs that keep changing.

(4) Movement: Children should be allowed to move their body without any restraints in the given space and posture in various ways to become more strong. One of the top priorities for the design of a children's space is to ensure their free movement. The environments should be able to stimulate them to learn how to move the body, to learn something by moving the body, to be engaged in a variety of muscular activities and ultimately to get their body and things in control.

(5) Self-esteem: In terms of emotional development, it's very crucial to approve of individual children as important ones and let them build self-confidence. But there may be a gap between their hope and actual ability to realize it, and they get disappointed when the gap is broad. To step up confidence building, they should be assisted to easily do what they want to do in order to gain successful interaction experiences with the world around them.

(6) Control: Children should be able to keep their privacy and control their own body within the given space. In a children's space, observation and approach are usually considered more important than privacy, and that may result in infringing on their privacy. Like adults, however, privacy is important for children, and their needs for that should be addressed. A private space is very vital for the development of self- concept and personal identity, and provides an opportunity for them to take a rest and get their mood, inner conflicts or emotion in control.

(7) Softness: Softness is one of the factors to ensure the comfortability of environments. A supply of soft environments makes children feel safe, and consequently encourages them to explore their surroundings, to do something they like and to refresh themselves. In terms of education, a supply of soft environments make it possible for them to learn from sensual experiences and feel pleasure, and it provides them with proximity that is necessary for verbal interaction and sociability acquisition. Such comfortability and softness are important for adults as well as children, and comfortable and soft environments play a crucial role in rest, stress removal and refreshment.

(8) Challenge: Children have a liking for the envi- 
184 Journal of the Korean Society for Information Management, 27(2), 2010

ronments that are exciting, challenging and give a chance to train the body. Furthermore, the development of the nervous system and sensory nerves is under the influence of the controllability of exposure to environmental stimuli. So children who are in a critical period of development should be allowed to interact with surrounding environments in an active and spontaneous way, and the sorts of challenging environments that let them learn to be careful and move safely through trial and error should be prepared.

(9) Privacy: Privacy is one of the fundamental barometers to determine the physical boundary between social units and the level of their interchange and separation and to regulate their interrelationship.

(10) Order: The spaces where people stay should be orderly for them to lead a healthy life. Children are likely to be attached to orderly spaces, and easily get familiar with the spaces. Children's environments should be orderly and well-regulated, and they should be provided with affluent environments that could give proper stimuli.

(11) Health: The environments provided to children should be like a warm and cozy house. The use of construction materials that are detrimental to health should be avoided, and the use of natural materials is recommended, instead. Artificial finish materials affects health, and such materials could provoke headache, respiratory diseases, eye diseases or nausea. How artificial finish materials affect health and hygiene isn't yet known, but natural materials should be utilized as many as possible to promote the health of adults and children. Table 5 shows the benefit items of children's spaces presented by different researchers.

〈Table 5〉 Benefit items on children's space by researcher

\begin{tabular}{|c|c|c|c|c|c|c|c|c|}
\hline $\begin{array}{l}\text { Kostelnik } \\
\text { (1997) }\end{array}$ & $\begin{array}{l}\text { Sanoff } \\
(1995)\end{array}$ & $\begin{array}{l}\text { Moore } \\
(1987)\end{array}$ & $\begin{array}{l}\text { Greenman } \\
\text { (1988) }\end{array}$ & $\begin{array}{l}\text { Castaldi } \\
\text { (1994) }\end{array}$ & $\begin{array}{l}\text { Decker } \\
(1976)\end{array}$ & $\begin{array}{c}\text { Hwang } \\
\text { Yeon-sook } \\
(2003)\end{array}$ & $\begin{array}{c}\text { Lee } \\
\text { Yeon-sook } \\
(1997)\end{array}$ & $\begin{array}{l}\text { Kim } \\
\text { Ju-kun } \\
(1992)\end{array}$ \\
\hline Security & Flexibility & Accessibility & Self-esteem & Sufficiency & Stability & Convenience & Movement & Safety \\
\hline Health & Surface & Security & Privacy & Appropriateness & Suitability & Accessibility & Comfortability & Flexibility \\
\hline Ease & Privacy & $\begin{array}{l}\text { Sense of } \\
\text { challenge }\end{array}$ & Softness & Efficiency & $\begin{array}{l}\text { Barrier-free } \\
\text { environment }\end{array}$ & $\begin{array}{c}\text { Order } \\
\text { characteristic }\end{array}$ & Self-esteem & Aesthetics \\
\hline Body size & $\begin{array}{c}\text { Visual } \\
\text { connection }\end{array}$ & Clarity & Movement & $\begin{array}{l}\text { Economic } \\
\text { efficiency }\end{array}$ & Efficiency & $\begin{array}{c}\text { Possibility of } \\
\text { expression }\end{array}$ & Control & Connectivity \\
\hline Flexibility & & Flexibility & Comfortability & Safety & Flexibility & Originality & Softness & $\begin{array}{l}\text { Economic } \\
\text { efficiency }\end{array}$ \\
\hline Movement & & Variety & Safety & Health & $\begin{array}{l}\text { Economic } \\
\text { efficiency }\end{array}$ & Safety & Challenge & Manageability \\
\hline \multirow[t]{5}{*}{ Selection } & & & Flexibility & $\begin{array}{c}\text { Convenient } \\
\text { characteristic }\end{array}$ & & Comfort & Privacy & \\
\hline & & & Health & Flexibility & & territoriality & Order & \\
\hline & & & Control & Adaptability & & Privacy & Security & \\
\hline & & & Challenge & Flexibility & & Interaction & Health & \\
\hline & & & Order & - & & & Flexibility & \\
\hline
\end{tabular}




\section{A Spatial Criteria Checklist of a Children's Library}

\subsection{Spatial Criteria for a Children's Library}

It's necessary to take a look at Murtha (1976)'s user benefit criteria once again, which was mentioned in Chapter 2, in order to develop a spatial criteria checklists of a children's library. What matters here is how the term benefit that admits of various inter- pretations should be explained. So earlier studies of children's libraries and children's spaces were analyzed to select another term that could corresponded to benefit.

To conceptualize the term benefit, corresponding words were extracted from earlier studies of children's libraries and children's spaces. Tables 6 and 7 respectively show the frequency of the corresponding terms in earlier studies of children's libraries and children's spaces.

〈Table 6〉 Appearance frequency of benefit items in the preceding researches on children's library

\begin{tabular}{|c|c|c|c|c|c|c|c|c|c|c|}
\hline Benefit items & $\begin{array}{c}\text { Gang } \\
\text { Geon-hae } \\
\text { (2006) }\end{array}$ & $\begin{array}{l}\text { Park } \\
\text { Soo-mi } \\
(2005)\end{array}$ & $\begin{array}{c}\text { Shin } \\
\text { Hyen-jeong } \\
\text { (2005) }\end{array}$ & $\begin{array}{c}\text { Oh } \\
\text { Ji-seon } \\
(2005)\end{array}$ & $\begin{array}{l}\text { Choi } \\
\text { Jin-hee } \\
\text { (2005) }\end{array}$ & $\begin{array}{c}\text { Park } \\
\text { Ji-min } \\
(2002)\end{array}$ & $\begin{array}{c}\text { Kim } \\
\text { Hee-jeong } \\
(2005)\end{array}$ & $\begin{array}{l}\text { Gang } \\
\text { Yoon-ho } \\
(2004)\end{array}$ & $\begin{array}{l}\text { Lee } \\
\text { Soo-yeon } \\
(2002)\end{array}$ & $\begin{array}{l}\text { Appearance } \\
\text { frequency }\end{array}$ \\
\hline Safety & - & - & - & - & - & - & - & - & - & 10 \\
\hline Flexibility & - & - & - & - & - & - & - & - & & 9 \\
\hline Ease & - & - & - & - & - & - & - & - & & 9 \\
\hline Scale & - & - & - & & - & - & - & - & - & 9 \\
\hline Comfort & & - & & - & - & - & - & & - & 6 \\
\hline territoriality & & - & & & - & & - & & & 3 \\
\hline Health & & & & & - & & - & - & & 3 \\
\hline $\begin{array}{c}\text { Convenient } \\
\text { characteristic }\end{array}$ & & & & - & - & & & - & & 3 \\
\hline Accessibility & - & & & & & & & & - & 2 \\
\hline Softness & - & & & & & - & & & & 2 \\
\hline Privacy & - & & & & & & & - & & 2 \\
\hline Maintenance & & - & & & & & & - & & 2 \\
\hline Motility & & & & & & & - & & & 1 \\
\hline
\end{tabular}

$\langle$ Table 7〉 Appearance frequency of benefit items in the preceding researches on children's space

\begin{tabular}{c|c|c|c|c|c|c|c|c|c|c}
\hline Benefit items & $\begin{array}{c}\text { Kostelnik } \\
(1997)\end{array}$ & $\begin{array}{c}\text { Sanoff } \\
(1995)\end{array}$ & $\begin{array}{c}\text { Moore } \\
(1987)\end{array}$ & $\begin{array}{c}\text { Greenman } \\
(1988)\end{array}$ & $\begin{array}{c}\text { Castaldi } \\
(1994)\end{array}$ & $\begin{array}{c}\text { Decker } \\
(1976)\end{array}$ & $\begin{array}{c}\text { Hwang } \\
\text { Yeon-sook } \\
(2003)\end{array}$ & $\begin{array}{c}\text { Lee } \\
\text { Yeon-sook } \\
(1997)\end{array}$ & $\begin{array}{c}\text { Kim } \\
\text { Ju-kun } \\
(1992)\end{array}$ & $\begin{array}{c}\text { Appearance } \\
\text { frequency }\end{array}$ \\
\hline Safety & $\mathbf{- 1}$ & & $\mathbf{-}$ & $\mathbf{-}$ & $\mathbf{-}$ & $\mathbf{-}$ & $\mathbf{-}$ & $\mathbf{-}$ & $\mathbf{\text { - }}$ & 8 \\
\hline Flexibility & $\mathbf{-}$ & $\mathbf{-}$ & $\mathbf{-}$ & $\mathbf{-}$ & $\mathbf{-}$ & $\mathbf{-}$ & & $\mathbf{-}$ & $\mathbf{-}$ & 8 \\
\hline Health & $\mathbf{-}$ & & & $\mathbf{-}$ & $\mathbf{-}$ & & & $\mathbf{-}$ & \\
\hline Privacy & & $\mathbf{-}$ & & $\mathbf{-}$ & & & $\mathbf{-}$ & $\mathbf{-}$ & & 4 \\
\hline $\begin{array}{c}\text { Economic } \\
\text { efficiency }\end{array}$ & & & & & $\mathbf{-}$ & $\mathbf{-}$ & & $\mathbf{-}$ & $\mathbf{-}$ & 4 \\
\hline
\end{tabular}


186 Journal of the Korean Society for Information Management, 27(2), 2010

〈Table 7〉 Appearance frequency of benefit items in the preceding researches on children's space

\begin{tabular}{|c|c|c|c|c|c|c|c|c|c|c|}
\hline Benefit items & $\begin{array}{l}\text { Kostelnik } \\
\text { (1997) }\end{array}$ & $\begin{array}{l}\text { Sanoff } \\
\text { (1995) }\end{array}$ & $\begin{array}{l}\text { Moore } \\
\text { (1987) }\end{array}$ & $\begin{array}{c}\text { Greenman } \\
\text { (1988) }\end{array}$ & $\begin{array}{l}\text { Castaldi } \\
\text { (1994) }\end{array}$ & $\begin{array}{l}\text { Decker } \\
(1976)\end{array}$ & \begin{tabular}{|c} 
Hwang \\
Yeon-sook \\
$(2003)$
\end{tabular} & $\begin{array}{c}\text { Lee } \\
\text { Yeon-sook } \\
(1997)\end{array}$ & $\begin{array}{c}\text { Kim } \\
\text { Ju-kun } \\
(1992)\end{array}$ & $\begin{array}{l}\text { Appearance } \\
\text { frequency }\end{array}$ \\
\hline Comfortability & - & & & - & & & & I & & 3 \\
\hline Movement & - & & & - & & & & - & & 3 \\
\hline Challenge & & & - & - & & & & - & & 3 \\
\hline Order & & & & - & & & - & - & & 3 \\
\hline Softness & & & & - & & & & - & & 2 \\
\hline Control & & & & - & & & & - & & 2 \\
\hline Efficiency & & & & & - & - & & & & 2 \\
\hline $\begin{array}{c}\text { Convenient } \\
\text { characteristic }\end{array}$ & & & & & - & & - & & & 2 \\
\hline Accessibility & & & - & & & & - & & & 2 \\
\hline Self-esteem & & & & - & & & & & & 1 \\
\hline Sufficiency & & & & &. & & & & & 1 \\
\hline Appropriateness & & & & & - & & & & & 1 \\
\hline Flexibility & & & & & - & & & & & 1 \\
\hline Adaptability & & & & & - & & & & & 1 \\
\hline Body size & - & & & & & & & & & 1 \\
\hline $\begin{array}{c}\text { Visual } \\
\text { connection }\end{array}$ & & - & & & & & & & & 1 \\
\hline Surface & & - & & & & & & & & 1 \\
\hline Suitability & & & & & & - & & & & 1 \\
\hline $\begin{array}{l}\text { Barrier-free } \\
\text { environment }\end{array}$ & & & & & & - & & & & 1 \\
\hline Aesthetics & & & & & & & & & - & 1 \\
\hline Connectivity & & & & & & & & & - & 1 \\
\hline Manageability & & & & & & & & & - & 1 \\
\hline Clarity & & & . & & & & & & & 1 \\
\hline Variety & & & - & & & & & & & 1 \\
\hline $\begin{array}{l}\text { Possibility of } \\
\text { expression }\end{array}$ & & & & & & & - & & & 1 \\
\hline Originality & & & & & & & - & & & 1 \\
\hline Comfort & & & & & & & - & & & 1 \\
\hline territoriality & & & & & & & - & & & 1 \\
\hline Interaction & & & & & & & - & & & 1 \\
\hline
\end{tabular}

Thus, most of the children's library researchers attached importance to security, flexibility, comfortableness, scale and amenity, whereas the researchers of children's spaces took a different view of every factor except security and flexibility. A noteworthy fact is that security and flexibility are considered important in both of children's libraries and spaces, and an in-depth analysis is consequently required in relation to the two factors. In this study, 10 items were selected as evaluation items of the spatial criteria of a children's library from earlier studies, which are security, flexibility, convenience, territoriality, amenity, comfortableness, self-esteem and aestheticity. The first two are considered vital in both of earlier studies on children's libraries and spaces. Convenience and territoriality were selected from both of earlier 
studies on children's libraries and spaces as well. Amenity and comfortableness were selected from earlier studies on children's libraries, and self-esteem and aesthetics were selected from earlier studies on children's spaces. Besides, this study gave additional weight to rest and communication, and the two factors were added. In total, 12 items were selected as evaluation items of the spatial standard of a children's library.

Thus, the items that were selected in this study as what corresponded the benefit of the user benefit criteria involved convenience, security, variety, aestheticity, dynamicity, flexibility, self-esteem, amenity, comfortableness, rest, communication and territoriality. The operational definition of the terms are as below:

(1) Convenience: Convenience refers to ease and convenience of use. It requires not only the installment of basic facilities and props but human- friendly spatial structure and human-friendly furniture arrangement. That is, it implies that children's library spaces should be easy to use physically.

(2) Security: This refers to a safe state in which there are no hazardous elements to pose a threat to the body. Children continue to move in a hasty manner owing to their motor skills, and they are usually careless at the same time. Moreover, infants and preschoolers who don't yet make a proper development in physical balance are highly likely to tumble down. Therefore the security of the spaces should be guaranteed in advance to prevent any possible accidents.

(3) Variety: This refers to a sort of appropriateness of a space and furniture. In other words, the spaces of a children's library should be different in size according to the figure of users of different ages, and the spaces should be equipped with the furniture that is different in size as well. There should be diverse spaces that can separately be used depending on the characteristics of age, developmental stage, gender and grouping.

(4) Aestheticity: The overall image of children's library spaces should be aesthetic. The spatial design and finish materials should be well matched to give an aesthetic impression.

(5) Dynamicity: This term means that a children's library should be multifunctional. In addition to reading, users should be allowed to participate in various cultural and play activities and to receive education.

(6) Flexibility: This term denotes that there should be no restrictions on the use of a children's library. The characteristics of children who prefer liberal atmosphere to controlled or stiff one should be valued, and a children's library should be variable so that it could be utilized in various ways according to the given circumstances.

(7) Self-esteem: This term refers to psychological satisfaction that children feel when they use a library. The library spaces should be designed to give young users satisfaction and heighten their pride.

(8) Amenity: This term denotes that a proper temperature, appropriate level of noise, optimum lighting and clean air are necessary to make users feel pleasant.

(9) Comfortableness: This term means that nature-friendly and child- oriented environments should be created to make them feel comfortable. A harmonious combination of artificial and natural aesthetics is required to make it happen. 
(10) Rest: Young users should be able to get rest whenever they want. One of children's characteristics is that they enjoy eating regardless of space and time.

(11) Communication: This term denotes an interchange of information and knowledge between people and between people and books, which is similar to the unique function of a library.

(12) Territoriality: This term refers to a specific zone of protection within an open space. The library spaces should enable children to keep their privacy.

\subsection{Cases of the Application of Children's Library Spatial Standards}

22 domestic and foreign children's libraries were selected to verify the applicability of the 12 items of four categories that were presented as the spatial conditions of a children's library to back up children's development. An on-the-spot probe was conducted, and the data about the selected libraries were analyzed. Since the 12 spatial criteria were selected based on relevant theories and earlier studies, it's required to check the practical applicability of the criteria.

〈Table 8> Image with application of the spatial standard for children's library (1)

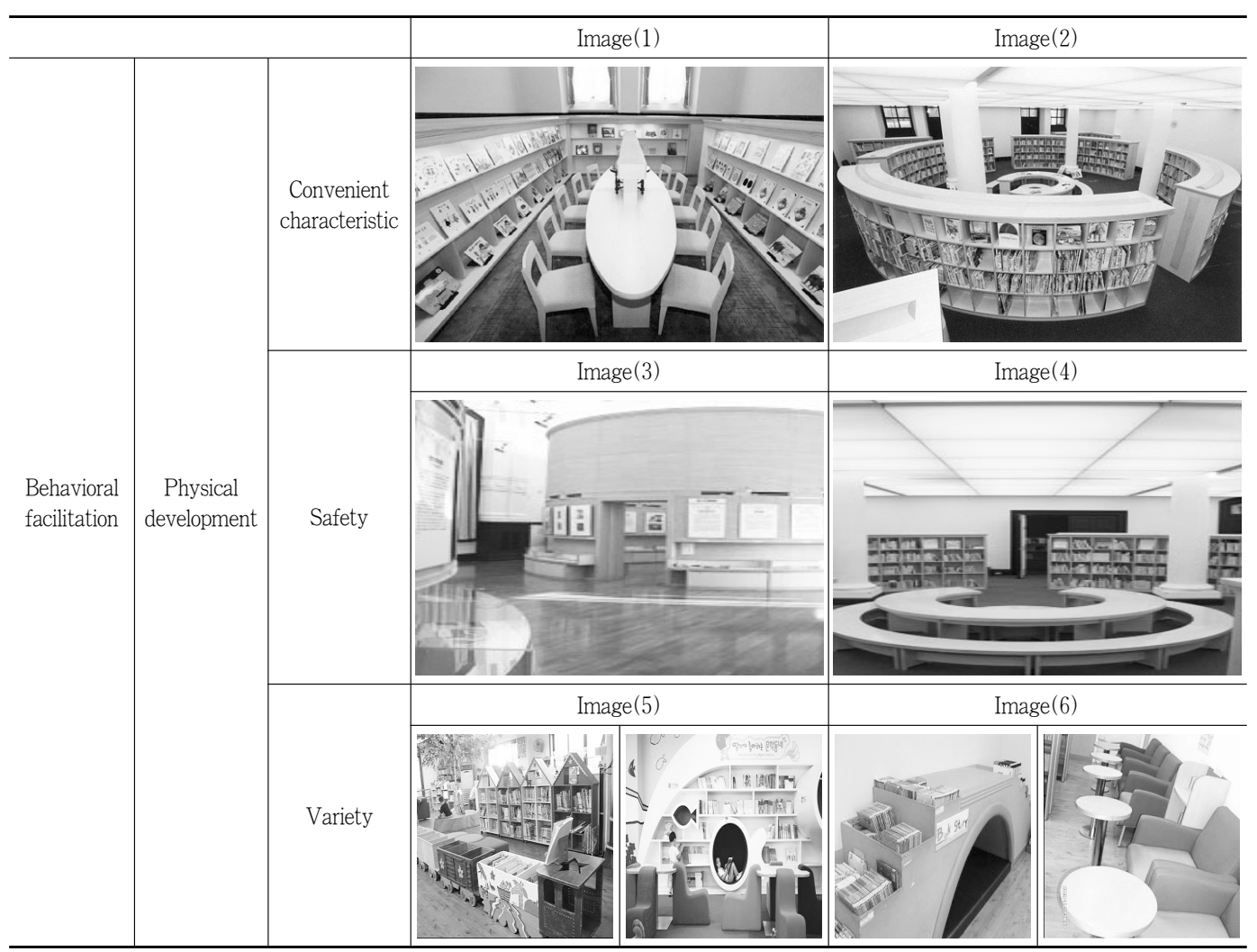


〈Table 8〉 Image with application of the spatial standard for children's library (1)

(continued)

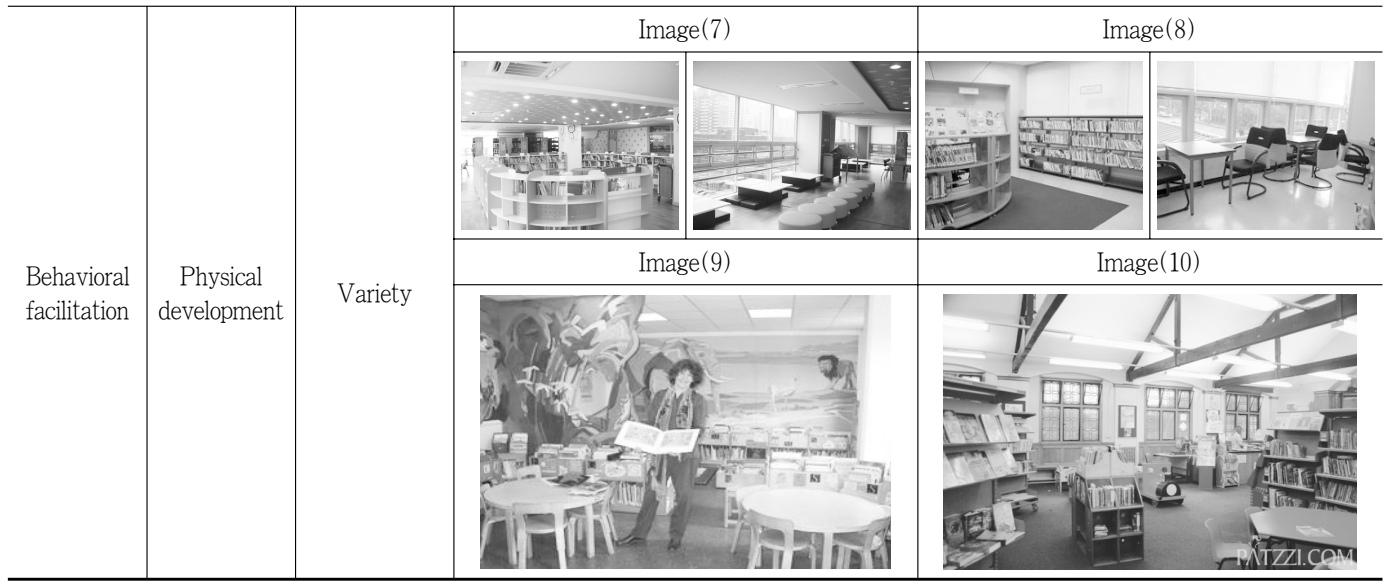

In Table 8, Images 1, 2, 3, and 4 are the complete views of the International Children's Library in Japan. The images are typical examples of convenience and security. Images 1 and 2 are excellent examples of convenience that give weight to user convenience. All the spaces of the images are well lighted evenly, and oval bookshelves are arranged in a three-dimensional way. There are chairs in both sides of reading tables encircled by the oval bookshelves, on which children and their guardians can sit face to face to read books. All the things are to give careful consideration to users. Images 3 and 4 are good examples of security. Sanitary raw timber was used as finish materials, and every corner of the furniture is round. Image 5 is a children's library named 'I won't go home,' and Image 6 is Siheung Children's Library. Image 7 is Okryeon Children's Library, and Image 8 is Anyang Children's Library. Image 9 is I'heure Joyeuse, a children's library in France, and Image 10 is Paddington Children's Library in England. All the libraries are equipped with various forms of bookshelves and tables from which children can choose according to their figure.

〈Table 9> Image with application of the spatial standard for children's library (2)

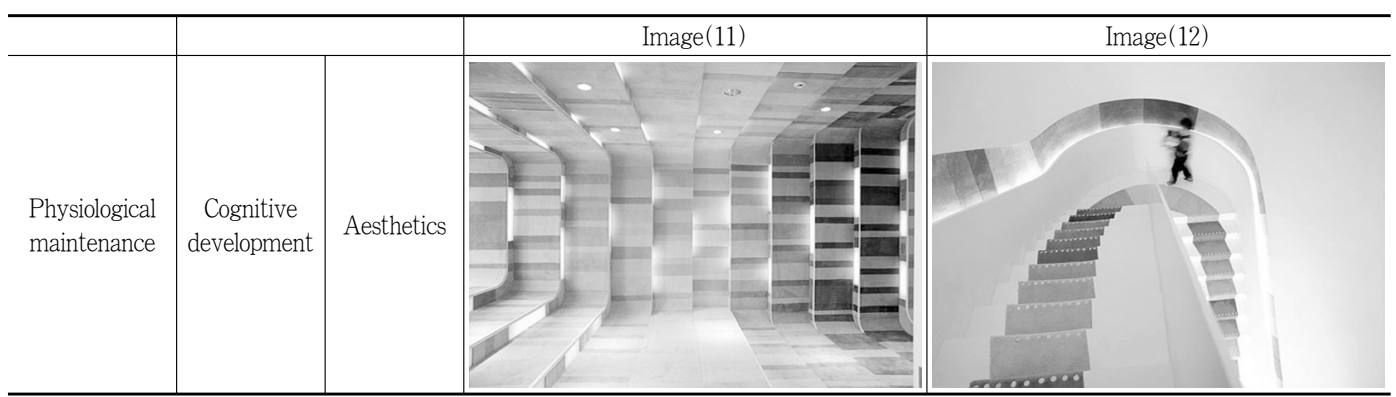


〈Table 9> Image with application of the spatial standard for children's library (2)

(continued)

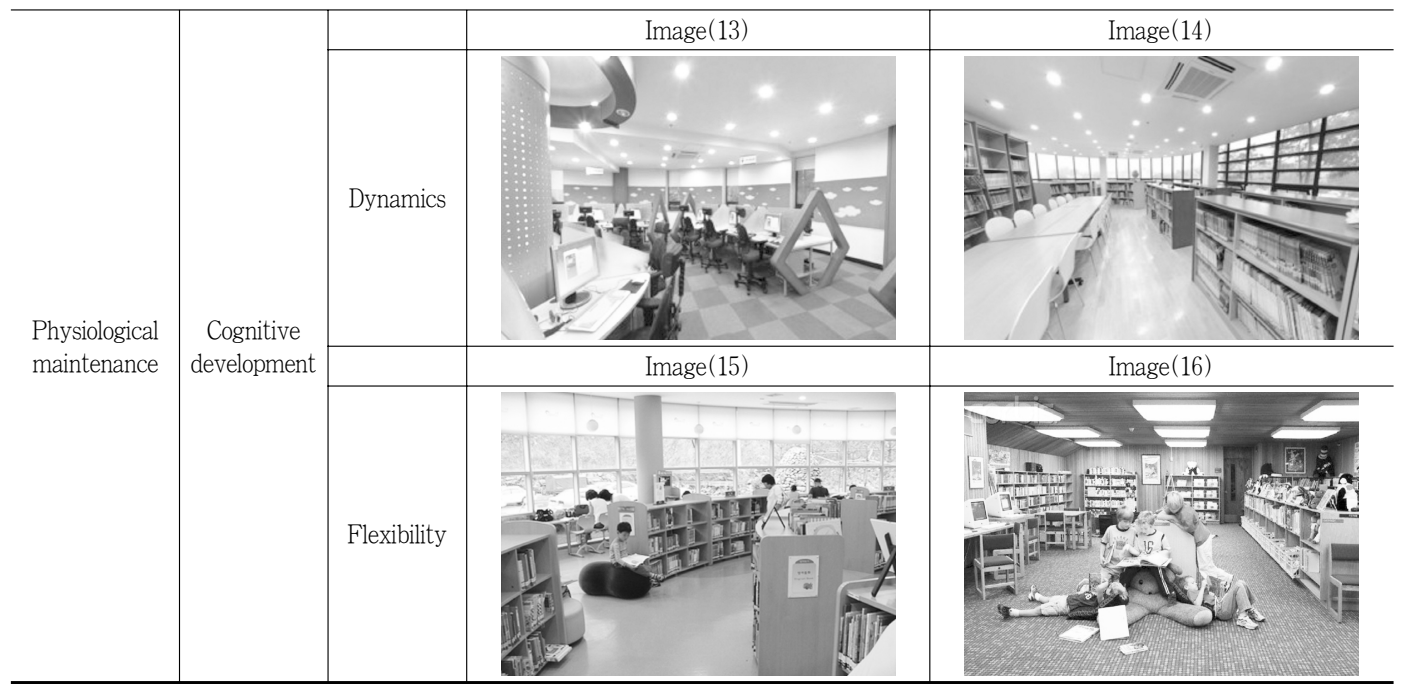

Images 11, 12, 17 and 18 are the views of Kids Republic in Beijing. Out of the images, Images 11 and 12 are typical examples of aestheticity. Image 11 shows the entrance of the library that takes the form of a rainbow by utilizing 12-color bands. Just the harmony of the colors is good enough to make the space aesthetic, and the geometric space gives stimuli to children's imagination and leads them into the world of their own. Image 12 is a twisting, slide-shaped bookshelf that reaches the ceiling through the wall. This bookshelf enables them to choose books with pleasure as if they played. Among various environmental components, color is the most integral one to affect potential human perception, emotion and behavior, and that is especially important for impressionable children. Images 13 and 14 are the looks of Yangpyeong Children's Library that gives an example of dynamicity. This library has good computer facilities and tables on which several children can sit together, which indicates that the library is not an exclusive space for reading but a dynamic activity place where users can search information over the Internet and have a discussion with one another about books they read. Images 15 and 16 that are respectively the views of Euijeongbu Children's Library and a public library in New York are good examples of flexibility. Children don't like stiff posture or controlled atmosphere. In those libraries, users can read books lying down at any place.

Images 17 and 18 are another views of Kids Republic in Beijing that give an example of selfesteem. Although the physical spaces of the libraries are similar to those of other libraries in size, the way of arranging the spaces makes them more significant and meaningful. The spatial construction that is implicitly aesthetic allows the libraries to serve as multipurpose hands-on spaces. Image 19 is the International Children's Library in Japan, and Image 
〈Table 10〉 Image with application of the spatial standard for children's library (3)

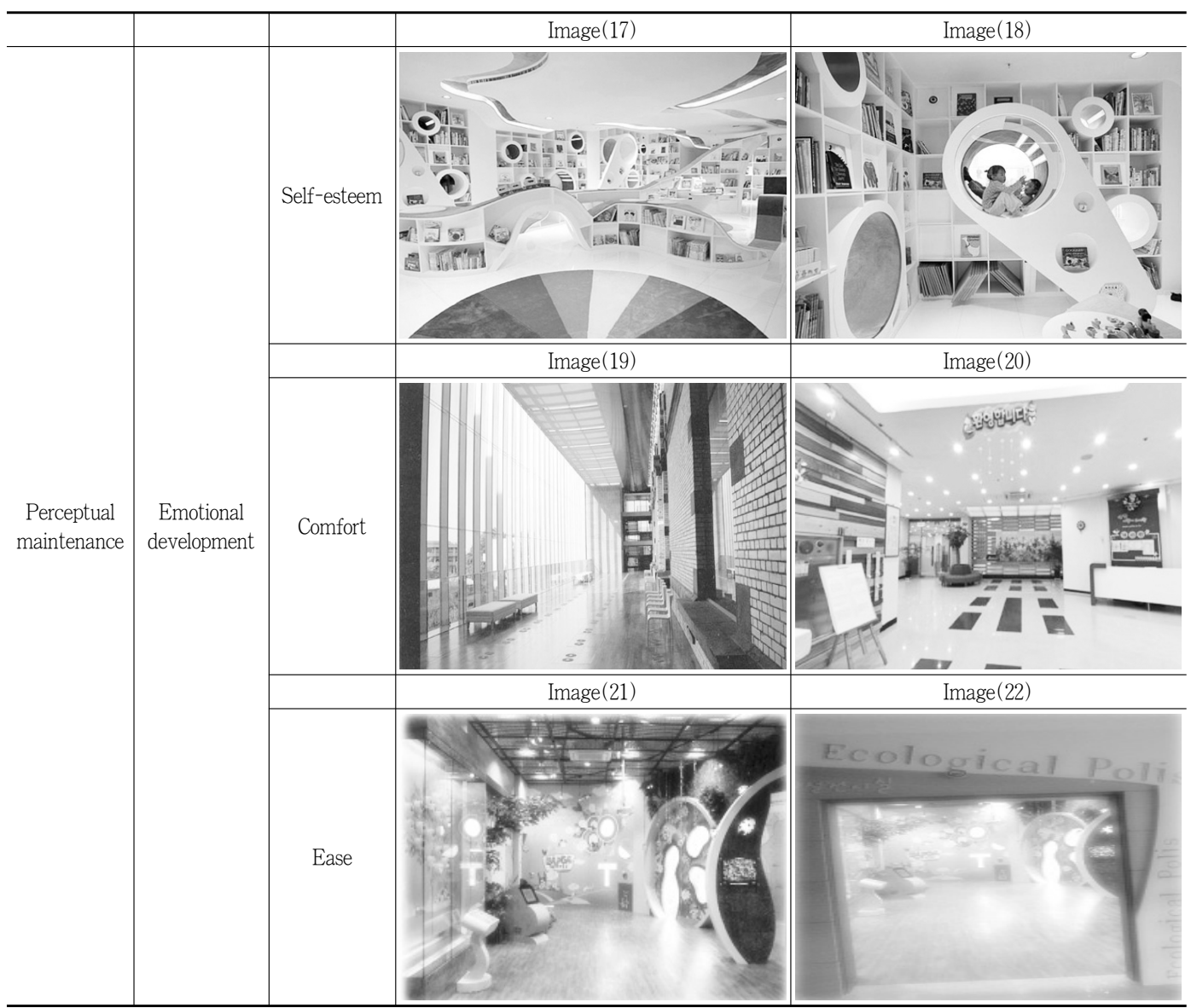

20 is Yangpyeong Children's Library. Both libraries are excellent examples of amenity, which are characterized by sanitary and clean environments involving the high ceiling, the walls made of natural materials such as bricks and raw timber, natural lighting through windows, and floor materials involving raw timber and marble. Images 21 and 22 are the looks of Children Ecology Study Library, and are good examples to show the mystery of nature. The man-made spaces are designed to give an impression of natural aesthetics, and users subsequently feel comfortable and are able to gain different hands-on experiences in the same space.

In Table 11, Image 23 of Anyang Children's Library and Image 24 of Nowon Children's Library are typical examples about the function of rest. A children's library is basically a place to read books, but one of the major characteristics of children is that they use a lounge often. So the lounge should be designed to be attractive as much as possible to step up sociability development. Image 25 is the children's room of a library in Jurong, Singapore, 
and Image 26 is Siheung Children's Library. Both of the images give an impression of communication. The children and adults read books together in a comfortable posture, and it looks like that the people communicate with one another and books. Image 27 of Youth \& Children's Library in Beijing, Image 28 of Anyang Children's Library, Image 29 of Yangpyeong Children's Library and Image 30 of the library named 'I won't go home' are all good examples of territoriality. Everybody prefers to have his or her own area even while being with others, no matter whether there is a visible or nonvisible boundary between that area and the other spaces. The territorialized spaces are peaceful refuge for children.

So far, the data of on-the-spot probe were reviewed to find out what kind of spatial construction could make a contribution to physical, cognitive, emotional and social development. 12 items that embodied the concept of benefit of the user benefit criteria were presented on the assumption that a children's library should back up children's development. And then a spatial condition checklist of a children's library is provided on that base.

〈Table 11〉 Image with application of the spatial standard for children's library (4)

S




\subsection{A Spatial Condition Checklist of a Children's Library}

It was explained that children's libraries support children's development, and that the concept of affordance provided by the libraries to children could be replaced with that of benefit based on the user benefit criteria. And the items that could embody the abstract concept of benefit were selected. In this chapter, a spatial condition checklist of a children's library is offered on the basis of the user benefit criteria to make it possible to evaluate the design of a children's library in consideration of children's benefits.

$\langle$ Table 12〉 Detailed checklist of the spatial standard for children's library

\begin{tabular}{|c|c|c|c|c|}
\hline $\begin{array}{l}\text { Standard for } \\
\text { user benefits }\end{array}$ & $\begin{array}{l}\text { Spheres of } \\
\text { support }\end{array}$ & Basic items & Detailed contents & $\begin{array}{l}\text { Subjects of } \\
\text { support }\end{array}$ \\
\hline \multirow{23}{*}{$\begin{array}{l}\text { Behavioral- } \\
\text { facilitation }\end{array}$} & \multirow{23}{*}{$\begin{array}{c}\text { Physical } \\
\text { development }\end{array}$} & \multirow{12}{*}{$\begin{array}{l}\text { Convenient } \\
\text { characteristic }\end{array}$} & - Whether a door was designed with light material & $\begin{array}{l}\text { Infants, } \\
\text { toddlers }\end{array}$ \\
\hline & & & - Whether the required space for 1 person was alloted properly & Whole \\
\hline & & & - Whether furniture and the facilities were considered physical scale & $\prime \prime$ \\
\hline & & & - Whether a plan for circulation was well made & $\prime$ \\
\hline & & & - Whether toys, blocks, and puzzle materials were prepared & $\begin{array}{l}\text { Infants, } \\
\text { toddlers }\end{array}$ \\
\hline & & & - Whether accessibility between domains is good & Whole \\
\hline & & & - Whether the operation in toilet and basin is easy & $\prime \prime$ \\
\hline & & & $\begin{array}{l}\text { - Appearance of being able to find a pathway by direction board, } \\
\text { open structure, and bottom difference }\end{array}$ & " \\
\hline & & & $\begin{array}{l}\text { - Whether personal locker, shoe rack, and drinking fountain were } \\
\text { equipped }\end{array}$ & $"$ \\
\hline & & & - Whether Search Carroll was fully distributed & Children \\
\hline & & & - Whether sign is visually effective & Whole \\
\hline & & & $\begin{array}{l}\text { - Whether bulletin board, wall-sticked matter, and displayed articles } \\
\text { are enough to make library known }\end{array}$ & Children \\
\hline & & \multirow{11}{*}{ Safety } & $\begin{array}{l}\text { - Appearance of having been designed so that children can move } \\
\text { safely }\end{array}$ & $"$ \\
\hline & & & $\begin{array}{l}\text { - Whether safety device was installed in order to prevent children } \\
\text { from falling }\end{array}$ & $"$ \\
\hline & & & - Whether rail, knob, and handle were installed safely & " \\
\hline & & & - Whether electric implements and wall outlets were installed safely & " \\
\hline & & & - Whether safety glass was used & " \\
\hline & & & - Whether artificial barrier was minimized & " \\
\hline & & & $\begin{array}{l}\text { - Whether edges in furniture and equipments were treated to be } \\
\text { rounding }\end{array}$ & $"$ \\
\hline & & & - Whether non-slip floor material was used & $\begin{array}{l}\text { Infants, } \\
\text { toddlers }\end{array}$ \\
\hline & & & - Whether the floor was made with flexible material & $\prime$ \\
\hline & & & $\begin{array}{l}\text { - Whether there are double doors in a place where children visit } \\
\text { frequently }\end{array}$ & $"$ \\
\hline & & & $\begin{array}{l}\text { - Appearance of being repaired the broken door, knob, bookshelf, } \\
\text { desk and chair }\end{array}$ & $"$ \\
\hline
\end{tabular}


194 Journal of the Korean Society for Information Management, 27(2), 2010

〈Table 12〉 Detailed checklist of the spatial standard for children's library(contiued)

\begin{tabular}{|c|c|c|c|c|}
\hline $\begin{array}{l}\text { Standard for } \\
\text { user benefits }\end{array}$ & $\begin{array}{l}\text { Spheres of } \\
\text { support }\end{array}$ & Basic items & Detailed contents & $\begin{array}{c}\text { Subjects of } \\
\text { support }\end{array}$ \\
\hline \multirow{11}{*}{$\begin{array}{l}\text { Behavioral- } \\
\text { facilitation }\end{array}$} & \multirow{11}{*}{$\begin{array}{c}\text { Physical } \\
\text { development }\end{array}$} & \multirow{11}{*}{ Variety } & - Appearance of being offered the space of the non-reading activity & Whole \\
\hline & & & $\begin{array}{l}\text { - Appearance of providing space in diverse forms such as the opened } \\
\text { and the closed }\end{array}$ & $"$ \\
\hline & & & $\begin{array}{l}\text { - Appearance of offering large scale, small-and-mid scale, and } \\
\text { individual reading space }\end{array}$ & $"$ \\
\hline & & & - Whether space was formed so that diverse programs can be operated & " \\
\hline & & & $\begin{array}{l}\text { - Appearance of having been arranged the bookshelf in diverse } \\
\text { forms available for causing interest }\end{array}$ & $\begin{array}{l}\text { Infants, } \\
\text { toddlers }\end{array}$ \\
\hline & & & $\begin{array}{l}\text { - Appearance of having been distributed the bookshelf in unique } \\
\text { character }\end{array}$ & $"$ \\
\hline & & & $\begin{array}{l}\text { - Appearance of being able to make children's sight concentrated } \\
\text { such as a picture on the wall and a mobile on the ceiling }\end{array}$ & Whole \\
\hline & & & - Whether there is accent-based element with diverse items & " \\
\hline & & & $\begin{array}{l}\text { - Appearance of offering colorful environment such as solo motor } \\
\text { cycle, cushion, and trifling articles of animals and plants }\end{array}$ & $"$ \\
\hline & & & $\begin{array}{l}\text { - Whether or not being the space of offering region-based, physical, } \\
\text { and cultural variety }\end{array}$ & $"$ \\
\hline & & & - Whether the reading room for the disabled was installed & " \\
\hline \multirow{20}{*}{$\begin{array}{l}\text { Physiological- } \\
\text { maintenance }\end{array}$} & \multirow{20}{*}{$\begin{array}{c}\text { Cognitive } \\
\text { development }\end{array}$} & \multirow{5}{*}{ Aesthetics } & $\begin{array}{l}\text { - Whether the whole space was designed in order to lead to aesthetic } \\
\text { sense }\end{array}$ & " \\
\hline & & & - Whether artificial lighting device was installed properly & " \\
\hline & & & - Whether natural lighting comes in well & " \\
\hline & & & $\begin{array}{l}\text { - Appearance of being soft and smooth in the finishing-material } \\
\text { texture of the ceiling, wall, and floor }\end{array}$ & $"$ \\
\hline & & & - Whether a coloring plan was properly made & " \\
\hline & & \multirow{8}{*}{ Dynamics } & - Whether the exhibition space of works was enough arranged & " \\
\hline & & & - Appearance of being enough for the space of theater and expression & " \\
\hline & & & - Whether audiovisual room was equipped & " \\
\hline & & & - Whether special-activity space is enough & " \\
\hline & & & $\begin{array}{l}\text { - Appearance of being enough for space available for being together } \\
\text { with parents }\end{array}$ & $"$ \\
\hline & & & - Appearance of being enough for club-activity space & " \\
\hline & & & - Whether the computer facilities are well furnished & " \\
\hline & & & - Appearance of being enough for book-impression activity space & " \\
\hline & & \multirow{7}{*}{ Flexibility } & $\begin{array}{l}\text { - Whether or not being the variable structure available for a change } \\
\text { anytime }\end{array}$ & Whole \\
\hline & & & - Whether or not being the open-styled space basically & " \\
\hline & & & $\begin{array}{l}\text { - Whether a wall by the window was made to be possibly used } \\
\text { like furniture }\end{array}$ & " \\
\hline & & & $\begin{array}{l}\text { - Appearance of structure that can utilize bookshelf as the simple } \\
\text { wall }\end{array}$ & $"$ \\
\hline & & & $\begin{array}{l}\text { - Appearance of being able to segment space with movable } \\
\text { partitioning }\end{array}$ & $"$ \\
\hline & & & $\begin{array}{l}\text { - Appearance of having been designed in order to be available for } \\
\text { public performance, viewing and exhibition off and on }\end{array}$ & $"$ \\
\hline & & & - Appearance of being available for re-distribution into diverse spaces & " \\
\hline
\end{tabular}


〈Table 12〉 Detailed checklist of the spatial standard for children's library(contiued)

\begin{tabular}{|c|c|c|c|c|}
\hline $\begin{array}{l}\text { Standard for } \\
\text { user benefits }\end{array}$ & $\begin{array}{l}\text { Spheres of } \\
\text { support }\end{array}$ & Basic items & Detailed contents & $\begin{array}{l}\text { Subjects of } \\
\text { support }\end{array}$ \\
\hline \multirow{27}{*}{$\begin{array}{l}\text { Perceptual- } \\
\text { maintenance }\end{array}$} & \multirow{27}{*}{$\begin{array}{c}\text { Emotional } \\
\text { development }\end{array}$} & \multirow{6}{*}{ Self-esteem } & $\begin{array}{l}\text { - Whether or not being mood available for mentally giving a } \\
\text { deeply satisfying feeling as cultural space }\end{array}$ & Children \\
\hline & & & $\begin{array}{l}\text { - Whether or not being space available for leading to intellectual } \\
\text { curiosity as the space of knowledge }\end{array}$ & $"$ \\
\hline & & & $\begin{array}{l}\text { - Whether or not being space available for giving a feeling as } \\
\text { saying of being respected fully }\end{array}$ & $"$ \\
\hline & & & $\begin{array}{l}\text { - Whether or not being a system available for being felt to be } \\
\text { protected, not controlled }\end{array}$ & $"$ \\
\hline & & & $\begin{array}{l}\text { - Whether or not being the spatial structure available for feedback } \\
\text { with a manager at library }\end{array}$ & $"$ \\
\hline & & & $\begin{array}{l}\text { - Appearance of having been designed so that enough freedom } \\
\text { can be enjoyed }\end{array}$ & \\
\hline & & \multirow{12}{*}{ Comfort } & $\begin{array}{l}\text { - Whether proper artificial lighting was installed in all the learning } \\
\text { spheres }\end{array}$ & Whole \\
\hline & & & - Whether the air conditioning facilities were equipped & Whole \\
\hline & & & - Whether the Humidity Controller was installed & " \\
\hline & & & - Whether the ventilation facilities were well equipped & " \\
\hline & & & - Whether the illuminance level is proper & " \\
\hline & & & - Whether soundproofing was well furnished & " \\
\hline & & & $\begin{array}{l}\text { - Whether the sound absorption materials were used in the ceiling, } \\
\text { floor, and wall }\end{array}$ & $"$ \\
\hline & & & $\begin{array}{l}\text { - Whether monorium, wood, linoleum, and carpet were used } \\
\text { properly }\end{array}$ & $"$ \\
\hline & & & - Whether mosquito net was installed enough & " \\
\hline & & & - Whether nontoxic paint was used & " \\
\hline & & & - Whether there is no furniture that the toxic surface is peeled & " \\
\hline & & & - Whether the ventilator in toilet was installed & " \\
\hline & & \multirow{9}{*}{ Ease } & - Whether the whole space shows the warm and cozy mood & Whole \\
\hline & & & $\begin{array}{l}\text { - Appearance of presenting the mood like a house, not the mood } \\
\text { like the facilities }\end{array}$ & $\begin{array}{l}\text { Infants, } \\
\text { toddlers }\end{array}$ \\
\hline & & & $\begin{array}{l}\text { - Appearance of being the floor material available for reading } \\
\text { with lying down and rolling over }\end{array}$ & Whole \\
\hline & & & $\begin{array}{l}\text { - Whether the structure is proper that is available for leaning } \\
\text { with standing when reading }\end{array}$ & Children \\
\hline & & & - Whether sofa, cushion and stool were prepared & Whole \\
\hline & & & - Whether tables such as round table and sitting table were prepared & Children \\
\hline & & & $\begin{array}{l}\text { - Whether the finishing treatment was well made in wiring of } \\
\text { a digital data room }\end{array}$ & Whole \\
\hline & & & $\begin{array}{l}\text { - Appearance of having secured the path width between bookshelf } \\
\text { and bookshelf and between desk and bookshelf }\end{array}$ & " \\
\hline & & & $\begin{array}{l}\text { - Whether the background noise was treated that can cover } \\
\text { excessive quietness }\end{array}$ & $"$ \\
\hline \multirow{3}{*}{$\begin{array}{l}\text { Social- } \\
\text { facilitation }\end{array}$} & \multirow{3}{*}{$\begin{array}{c}\text { Social } \\
\text { development }\end{array}$} & \multirow{3}{*}{ Rest } & - Whether the rest space is arranged every proper space & Children \\
\hline & & & $\begin{array}{l}\text { - Whether the facilities such as beverage vending machine are } \\
\text { well equipped }\end{array}$ & " \\
\hline & & & - Whether the convenient facilities such as cafeteria are furnished & " \\
\hline
\end{tabular}


196 Journal of the Korean Society for Information Management, 27(2), 2010

$\langle$ Table 12〉 Detailed checklist of the spatial standard for children's library(contiued)

\begin{tabular}{|c|c|c|c|c|}
\hline $\begin{array}{l}\text { Standard for } \\
\text { user benefits }\end{array}$ & $\begin{array}{l}\text { Spheres of } \\
\text { support }\end{array}$ & Basic items & Detailed contents & $\begin{array}{l}\text { Subjects of } \\
\text { support }\end{array}$ \\
\hline \multirow{19}{*}{$\begin{array}{l}\text { Social- } \\
\text { facilitation }\end{array}$} & \multirow{19}{*}{$\begin{array}{c}\text { Social } \\
\text { development }\end{array}$} & \multirow{3}{*}{ Rest } & - Whether a mother-and-child room was equipped & $\begin{array}{l}\text { Infants, } \\
\text { toddlers }\end{array}$ \\
\hline & & & - Whether the sleeping space for infants and toddlers were provided & " \\
\hline & & & - Whether a bed for toddlers was equipped & toddlers \\
\hline & & \multirow{6}{*}{ Communication } & $\begin{array}{l}\text { - Whether the window was treated that can take a view of the } \\
\text { external world }\end{array}$ & Whole \\
\hline & & & - Whether the internal and external space was visually connected & " \\
\hline & & & - Appearance of offering a place of understanding other culture & " \\
\hline & & & $\begin{array}{l}\text { - Whether there are space and equipments available for interaction } \\
\text { between generations }\end{array}$ & $"$ \\
\hline & & & $\begin{array}{l}\text { - Appearance of being the facilities available for communication } \\
\text { on region }\end{array}$ & $" \prime$ \\
\hline & & & $\begin{array}{l}\text { - Appearance of being equipped with the basic facilities available } \\
\text { for communicating with the external world }\end{array}$ & Children \\
\hline & & \multirow{10}{*}{ territoriality } & $\begin{array}{l}\text { - Appearance of having divided the static sphere and the dynamic } \\
\text { sphere }\end{array}$ & $"$ \\
\hline & & & $\begin{array}{l}\text { - Appearance of having divided the noise space and non-noise } \\
\text { space }\end{array}$ & $\begin{array}{l}\text { Infants, } \\
\text { toddlers }\end{array}$ \\
\hline & & & - Whether the individual sphere is offered & Whole \\
\hline & & & $\begin{array}{l}\text { - Appearance of having divided the space for infants and toddlers } \\
\text { and the space for children }\end{array}$ & Whole \\
\hline & & & $\begin{array}{l}\text { - Whether there is territory of the learning space and the } \\
\text { non-learning space }\end{array}$ & $\prime \prime$ \\
\hline & & & - Appearance of having divided the space for guardians & $\begin{array}{l}\text { Infants, } \\
\text { toddlers }\end{array}$ \\
\hline & & & $\begin{array}{l}\text { - Whether or not being enough for space of protecting visual } \\
\text { and auditory privacy }\end{array}$ & Whole \\
\hline & & & $\begin{array}{l}\text { - Appearance of being territorialized a platform, stairs, slope way, } \\
\text { slide, and tunnel }\end{array}$ & $\begin{array}{l}\text { Infants, } \\
\text { toddlers }\end{array}$ \\
\hline & & & - Whether there are spheres of using object and props & Whole \\
\hline & & & $\begin{array}{l}\text { - Appearance of being available for the division of sphere by } \\
\text { age, by program, and by reading type }\end{array}$ & $\prime \prime$ \\
\hline
\end{tabular}

\section{Conclusion}

Children's libraries have drawn growing attention from the public, and a lot of research efforts have been directed into this matter. Nonetheless, there isn't a full understanding about children's development and ways of supporting them. How much children can benefit from a children's library hinges on the spatial construction of the library, and their development may be under the influence of that as well. The results of the study were as follows: First, the spatial construction of a children's library was discussed from a perspective of children's development, which is one of major themes in other academic communities, in order to take a systematic approach to the organic relationship between physical environ- 
ments and children. Second, the user benefit criteria that were typically utilized to assess children's spaces were applied to children's libraries, and the term benefit was embodied to present a conceptual framework. Third, the embodied concept of benefit was applied to library spaces to make it clear that the spaces of a children's library could be arranged by the user benefit criteria, and that the level of benefit provided to children might depend on the spatial construction. Fourth, the spatial condition checklist of a children's library was developed, which could be utilized as evaluation criteria of the design of a children's library that focuses on the concept of benefit provided to children.

\section{References}

Altman, I. 1975. The Environment and Social Behavior. Monterey, CA.: Brooks/Cole Pub. Co.

Berlyne, D. E. and F. D. Frommer. 1966. "Some

Determinants of Incidence and Content of Children's Questions.” Child Development, 37(1): 177-189.

Butler, A., E. E. Gotts, and N. L. Quisenburg. 1975. Early Childhood Programs: Development Objectives and Their Use. Columbus, Ohio: Charles E. Merrill Publishing Company.

Castaldi, B. 1994. Educational Facilities: Planning, Remodeling, and Management. Boston, M.A.: Allyn and Bacon Inc.

Cho, Bok-Hee. 2009. Child Development. Seoul: Kyoyookgwhaksa.

Choi, Jin-Hee. 2005. A Study on the Interior Design Planning of A Child-library for Preschool Children - Focused on Children Ages 1 to Preschooler. M.A. thesis. Sang Myung University.

Decker, C. A. and J. R. Decker. 1976. Planning and
Administering Early Childhood Programs. Columbus: Charles E. Merrill Publishing Company.

Evans, G. W., W. Kliewer, and J. Martin. 1991. "The role of the physical environment in the health and Well-being of children." Edited by $\mathrm{H}$. E. Schroeder. New Directions in Health Psychology Assessment. New York: John Wiley \& Sons.

Fisher, J. D., P. A. Bell, and A. Baum. 1984. Environmental Psychology. New York: Holt, Rinehart and Winston.

Gallahue, D. L. 1976. Motor Development and Movement Experiences for Young Children. New York: Random House. 1979. Fundamental Movement Patterns: A Developmental and Remedial Approach. Philadelphia: Saunders, Pincus, J. H. \& Chutorian, A.

Gang, Geon-Hae. 2006. On Relationship Between Reading Space and Behavior in Children's 
198 Journal of the Korean Society for Information Management, 27(2), 2010

Library: A Case Study of The Miracle Library. M.A. thesis. University of Ulsan.

Gang, Yoon-Ho. 2004. A Study of Furniture Arrangement in a Children's Reading Room of Public Library, Based on the Space Plan. M.A. thesis. Kyonggi University.

Gibson, J. J. 1972. Educational Psychology. New York: Appleton-Century-Crafts, Meredith Crop.

1979. The Ecological Approach to

Visual Perception. Boston, M.A.: Houghton Mifflin.

Glanzer, M. 1958. "The Role of Stimulus Satiation in Spontaneous Alternation." Journal of Comparative and Physiological Psychology, 51(3): 332-335.

Greenman, J. 1988. Caring Space, Learning Place: Children's Environment That Work. Redmond. WA.: Exchange Press Inc.

Halseth, G. and J. Doddridge. 2000. "Children's Cognitive Mapping: a Potential Tool for Neighbourhood Planning." Environment and Planning B-Planning \& Design, 27(4): 565582.

Hendrick, J. 1975. The Whole Child, New Trends in Early Education. Saint Louis: C.V. Mosley Company.

Herron, R. E. and Sutton-Smith. B. 1971. Social Play in Childhood. New York: Wiley.

Hurlock, E. B. 1964. Child Development. New York: McGrow-Hill Book.

Hwang, Yeon-Sook and Yeon-Sook Lee. 2003. “A Study on the Effect of Physical Environment on Childroom on Children's Emotion.” Journal of the Korean Housing Association, 14(5): 95-104.

Kang, Kyung-Mee. 2005. Child Development. Seoul: Daeyangsa.

Kim, Hee-Jeong. 2005. A Study on Planning Children's Reading Room within a Public Library Based on Child Development and Psychological Approach. M.A. thesis. Konkuk University. Kim, Ju-Kun. 1992. The Management of Early Childhood Educare-Center. Seoul: Chagzisa. Kohlberg, L. and R. Kramer. 1969. "Continuities and Discontinuities in Childhood and Adult Moral Development." Human Development, 12(2): 93-120.

Kostelnik, M. J. 1997. Spaces to Learn and Grow: Indoor Environments in Early Childhood Education. Seoul: Samsung Child Development Center.

Lee, Sang-Bok, Jeong-Mi Lee, Dong-Wha Kwack, and Che-Jin Lim. 2008. "A Basic Study on the Making a Pattern Language for the Architectural Design of Public Libraries.” Journal of the Korean Library and Information Society, 42(2): 421-444.

Lee, Soo-Yeon. 2002. (A) Study on the Libraries Services and the Visitor's Utilization at the Children's Reading Room. M.A. thesis. Yonsei University.

Lee, Yeon-Sook. 1997. Design Theory for Child Care Space. Seoul: Kyoyookgwhaksa.

Lim, Jae-Tack. 1995. The Operation and Management of Early Childhood Educare-Center: Kinder- 
garten and Child Care Center. Seoul: Yangsuhwon.

MaCandless, B. R. 1967. Child Behavior and Development. 2nd ed. New York: Holt, Rinehart and Winston

MaCandless, B. R. and E. D. Evans. 1973. Children and Youth, Psychosocial Development. Hansdale, Illinois: Dryden Press.

Moore, G. T. 1987. The physical environment and cognitive development in Child-care center. Edited by C. S. Weinstein and T. G. David. Space for Children: The Built Environment and Child Development. New York: Plenum Press.

Moore, G. T. 2002. 'Designed Environments for Young Children: Empirical Findings and Implications for Planning and Design." Children and Young People's Environments, 12(24): 53-63.

Murtha, M. D. 1976. Dimension of User Benefits: An Overview of User Oriented Environmental Design. Washington, DC.: American Institute of Architects.

Oh, Jee-Sun. 2005. A Renovation Plan for Public Children's Library on Children's Play Pattern. M.A. thesis. Hongik University.

Olds, A. R. 1989. "Psychological and Psychological Harmony in Child Care Center Design." Children's Environments Quarterly, 6(4): 23-37.

Osmon, F. L. 1973. Patterns for Designing Children's Center. New York: Educational Facilities Laboratories.

Park, Ji-Min. 2002. A Study on Planning Interior Space for Children's Library. M.A. thesis. Yonsei
University.

Park, Soo-Mi. 2005. A Study on the Space Com-position with the Typological Analysis of Children's Library. M.A. thesis. Dankook University. Sannwald, W. 2007. "Designing Libraries for Customers." Library Administration and Management, 21(3): 131-138.

Sanoff, H. 1995. Creating Environments for Young Children. Washington DC: Endowment of the Arts.

Sherman, S. A., J. W. Varni, and S. M. McCuskey. 2005. "Children's Environments and HealthRelated Quality of Life: Evidence Informing Pediatric Healthcare Environmental Design.” Children, Youth and Environments, 15(1): 186-223.

Shin, Hyen-Jeong. 2005. A Study on the Architectural Planning of a Children's Library. M.A. thesis. Seoul National University.

Spence, J. C. 2008. "Influence of Neighbourhood Design and Access to Facilities on Overweight Among Preschool Children.” International Journal of Pediatric Obesity, 2(3): 109-116.

Thorndike, E. L. 1949. Psychology and The Science of Education. New York: Lencke and Buechner.

Weinstein, C. A. 1987. Designing Preschool Classrooms to Support Development. New York: Plenum Press.

Yim, Mi-Sook, Kyung-Il Jung, and Eun-Ju Shin. 2004. Planning Guidelines of Living Place Children in KNHC. Seoul: Housing \& Urban Research Institute Korea National Housing Corporation. 